\title{
Livable Housing Design: The voluntary provision of inclusive housing in Australia
}

\section{Margaret Ward}

Queensland University of Technology

\section{Jill Franz}

Queensland University of Technology

\author{
Barbara Adkins \\ Queensland University of Technology
}

\begin{abstract}
This paper reports on a study of the voluntary provision of inclusive housing. The impetus for the study is the Livable Housing Design initiative, an agreement among Australian housing industry and community leaders in 2010 to a national guideline and voluntary strategy with a target to provide minimum access features in all new housing by 2020. Situated in and around Brisbane, Australia, the study problematises the assumption that the housing industry will respond voluntarily; an assumption which this study concludes is unfounded. The Livable Housing Design initiative asks individual agents to consider the needs of people beyond the initial contract, to proceed with objective reasoning and to do the right thing voluntarily. Instead, the study found that interviewees focused on their immediate contractual obligations, were reluctant to change established practices and saw little reason to do more than was legally required of them. This paper argues that the highlycompetitive and risk-averse nature of the industry works against a voluntary approach for inclusive housing and, if the 2020 target of the Livable Housing Design
\end{abstract}


initiative is to be reached, a mandated approach through legislation will be necessary. The Livable Housing Design initiative, however, has an important role to play in preparing the Australian housing industry to accept further regulation.

Keywords: Design, housing, inclusion, livable, visitability, voluntary

\section{Introduction}

At the age of fifty, Joan has a tertiary education, thirty years' work-experience, a family and a vibrant network of friends. Yet, in her adult life she has visited only five homes. She is not a social pariah-she uses a wheelchair. Her inability to enter and use most dwellings points to an "architectural apartheid" (Beck, 1996, p. 119); a systemic exclusion of people with a disability through mainstream housing design and construction. Australian governments at all levels, through the Council of Australia Governments, have committed to greater social inclusion (Australian Government, 2010), to upholding the human rights of people with a disability (Australian Government, 2011a) and to making cities more liveable (Australian Government, 2011b). To date, these commitments have given the housing industry little impetus to build more inclusive residential environments. This paper reports on a qualitative study which explored the responses by developers, designers and builders in the housing industry to providing inclusive housing; that is, what they perceived to be the barriers and what they considered might assist in providing inclusive housing as part of mainstream building practice.

The paper uses the term 'inclusive housing' to describe both social and private housing, including both single family homes and multi-unit developments, designed and built to facilitate the participation of all people in everyday domestic life in regular neighbourhoods (Milner \& Madigan, 2004). What this means in practical terms is widely debated (Bringolf, 2009); this paper uses the idea of "visitability"; a concept which "ensures that a basic level of accessibility will be provided in all housing, and . . . opens opportunities for participation in community life" (Truesdale, Steinfeld, \& Smith, 2002, pp. 8-9). Visitability has three principles: the first is that basic physical access to and within a dwelling should be a prerequisite rather than an optional extra feature; the second is that, through good design, this access can be provided at no 
or minimal cost; and the third is that assigning priority to the most important features will enhance its acceptance and provision (Maisel, 2006).

The study found that what appears to be a common-sense idea is unlikely to be adopted voluntarily as mainstream building practice. Housing providers saw little reason to provide inclusive housing within their interdependent, highly-competitive and risk-averse industry. If change is deemed necessary by a higher authority, such as a government committed to social inclusion, they preferred a regulatory approach so that everyone must comply - to minimise risk, to provide certainty and to remain competitive in the housing market.

\section{Background}

In 2010, the Australian Government brought together the national housing industry and community leaders to develop a plan to address the lack of inclusive housing. The agreement, called the Livable Housing Design initiative, aims to transform current housing practice to provide inclusive housing voluntarily. It has a national guideline and a plan. The guideline describes a minimum or Silver level (National Dialogue on Universal Housing Design [NDUHD], 2010a) with an aspirational target of all new housing providing Silver Level by 2020 (NDUHD, 2010b). Interim targets are also set; the first being $25 \%$ by 2013 , followed by $50 \%$ by 2015 and $75 \%$ in 2017 . More ambitious targets are set for the social housing sector. The Silver level comprises eight features, listed in Appendix A. The plan is to increase the demand for inclusive housing by buyers, promote and recognise industry leadership, provide incentives through accreditation, and advocate for the adoption of the guidelines in public policy (NDUHD, 2010b).

The Australian housing industry has seen a number of voluntary initiatives in the last two decades (Department of Public Works, 2008; Master Builders Association (ACT), 2001; Standards Australia, 1995; Victorian Building Commission, 2009). These have had minimal impact on the current supply of, or the demand for, inclusive housing (Bringolf, 2011b; Karol, 2008). The Livable Housing Design initiative differs from these predecessors in three ways: it takes a national focus; it has the support of both community and industry leaders; and there is a commitment within the plan to monitor its progress (NDUHD, 2010b).

The experiences of other voluntary initiatives serve to question whether the Livable Housing Design initiative will work. In comparative reviews of policies and 
programs in Europe, North America, United Kingdom, Japan and Australia (Imrie, 2006, pp. 69-72; Scotts, Saville-Smith, \& James, 2007), legislation is found to provide the most reliable, if reductionist, response and works best when supported by education and training. The housing industry typically resists regulation for inclusive housing and questions the legitimacy of need citing lack of demand from buyers, implementation challenges and unnecessary additional cost, (Imrie, 2006; Nishita, Liebig, Pynoos, Perelman, \& Spegal, 2007). A case-study in Irvine, California, found that, even when all stakeholders understand the reason for inclusive housing and agree to a voluntary approach, consistency of standard and supply are difficult to achieve (Kaminski, Mazumdar, DiMento, \& Geis, 2006).

In the United Kingdom, basic requirements for visitability have been mandated for all new housing since 1999 in response to the failure of previous voluntary strategies (Imrie, 2006). Imrie argues that mandated minimum access standards were necessary even though they do not address the access needs of many people with more significant disabilities, and they inhibit innovative building practice. Research in Japan, an ageing country, suggests that their voluntary approach using incentives will neither meet their burgeoning need for inclusive housing nor is the standard of access adequate (Kose, 2003, 2010). With these experiences from overseas in mind, the paper now describes the current Australian context where government, industry and community leaders are relying on the voluntary transformation of the housing industry to provide inclusive housing.

\section{Australian context}

The supply of inclusive housing in Australia is influenced by four key stakeholders: governing authorities; buyers of new housing; people who need inclusive housing; and the housing industry. Previously noted, governments across Australia have set a policy direction towards inclusive residential communities (Australian Government, 2010, 2011a) ratifying the Convention on the Rights of People with Disabilities (the Convention) supporting people with a disability to "full and effective participation and inclusion in society" and to "choose their place of residence and where and with whom they live on an equal basis with others". The Convention also supports the concept of universal design in the development of standards and guidelines in a way that requires "the minimum possible adaptation and the least cost to meet the specific needs of a person with disabilities" (United Nations, 2007). 
The Australian Government is relying on the anticipated outcomes of the Livable Housing Design initiative to respond to its obligations under the Convention (Australian Government, 2011a), to meet inclusive housing objectives in urban policy (Major Cities Unit, 2012) and, in part, to optimise home-based care of older Australians (Productivity Commission, 2011). State and local governments traditionally are reluctant to regulate how housing is designed and constructed; deferring to the Australian Building Codes Board (ABCB) to develop a nationallyconsistent mandated code of practice (ABCB, 2011). The ABCB, in turn, takes a mandatory approach only when there are 'flow-on' effects from market-failure that justify intervention.

There is minimal demand from buyers of new housing to include access features. This appears to be for three reasons. First, buyers are typically disinterested in paying for added features that are for the 'common good' or for which there is no personal or immediate benefit (Crabtree \& Hes, 2009; Spanbroek \& Karol, 2006). Second, volume builders have difficulty in changing their established building processes without incurring costly errors and delays (Dalton, Wakefield, \& Horne, 2011) resulting in a reluctance to respond to individual requests for access features (Bringolf, 2011a). Third, those people who need inclusive housing are not typically the buyers of new housing. One would expect older people, people with a disability, and their families to be potential buyers, given their need; however, most older people prefer to remain in their existing housing for as long as possible, and modify when necessary (Judd, Olsberg, Quinn, \& Demirbilek, 2010). Many families of people with a disability find changing their housing and communities problematic. After finding appropriately-designed housing and establishing their support networks, employment and transport, they typically 'stay put' for a long time (Beer \& Faulkner, 2009). People with disability report significantly lower incomes and are less likely to be home owners, much less buyers of new housing (Australian Institute of Health and Welfare [AIHW], 2012).

The lack of inclusive housing has significant consequences for people with a disability; it been found to contribute to their isolation, exclusion and marginalisation, which result in an over-dependency on social welfare, 'specialist' and social housing, and their families for housing and support (Beer \& Faulkner, 2009; National People with Disabilities and Carer Council, 2009; Saugeres, 2010). The need for inclusive housing is unlikely to decrease with nearly one-in-five people living with a disability 
and nine-out-of-ten people in this group having a specific limitation or restriction in daily living (Australian Bureau of Statistics, 2010a). Quantitative studies (Smith, Rayer, \& Smith, 2008; Smith, Rayer, Smith, Wang, \& Zeng, 2012) in the United States of America, which has a similar demography to Australia (US Census Bureau, 2008), suggest that over ninety per cent of newly-constructed, single-family dwellings will house at least one resident or receive a visitor with a long-term physical limitation during its lifespan. It is understandable, then, that advocates for people with disability and older people have called for a mandated approach to address this need (Australian Network for Universal Housing Design, 2011; Disability Investment Group, 2009; People with Disability Australia, 2010).

The Australian housing industry is a competitive, interdependent network of developers, suppliers and contractors driven by satisfactory contractual completion and profit. In the main, the industry has handed over the tasks of defining building quality, long-term planning, and sustainability of the built-environment to higher authorities, in particular, government planners and regulators (Dalton, Chhetri, Corcoran, Groenhart, \& Horne, 2011). Housing industry leaders acknowledge the importance of national consistency through regulation for commercial reasons: "It [is] near impossible . . . to become more efficient and continue to maintain cost-effective built products while building regulation systems differ from state to state" (Housing Industry Association submission cited in Productivity Commission, 2004, p. 78). They argue, however, against both regulation and the speculative provision for inclusive housing, and consider its provision to be the responsibility of individual buyers and government (Housing Industry Association, 2010, 2011).

So the challenge for the Livable Housing Design initiative is to find a way forward that meets the needs of the four stakeholders: the higher governing authorities-to meet their policy obligations; buyers-to have affordable options and choice; people who need inclusive housing-to find a place to live; and the housing industry-to meet their contractual obligations and remain competitive. The study emerged from this conundrum and problematised the assumption that the housing industry will respond voluntarily.

The study identified three supporting assumptions to the assumption of voluntariness from the documents describing the Livable Housing Design initiative. The first is trusteeship; that housing providers will consider the needs of occupants and visitors of the dwelling throughout its lifetime. The Livable Housing Design 
initiative encourages housing providers to "enhance the quality of life for all occupants at all stages of their life (sic) by including safer and more user friendly design features" (NDUHD, 2010b). The second is self-determination; that is, individual housing providers will proceed with objective reasoning to meet what is considered by their leaders to be a reasonable guideline, plan and set of targets within their business constraints (NDUHD, 2010b, p. 7). The third is sense-of-duty; that is, they prefer to do the right thing voluntarily before being directed to do so. It does this by assuming that individual agents will transform their practice voluntarily and creatively rather than having to comply with regulation (NDUHD, 2010b). The paper now turns to the methods and the results of the study and uses these three assumptions to guide the discussion.

\section{Method}

This qualitative study took a stance of critical inquiry using immanent critique (Sabia, 2010). It attempted to 'stand in the shoes' of individual developers, designers and builders to 'test' the three assumptions of the Livable Housing Design initiative (trusteeship, self-determination, and sense-of-duty) from their viewpoint. The study took place in and around Brisbane, Australia, and selected eleven newly-constructed mainstream dwellings as a theoretical sample from three housing contexts: privatelydeveloped housing, social housing (subsidised housing for people in housing need) and affordable housing developed by the Queensland Government's former Urban Land Development Authority. It used the Livable Housing Design's minimum or 'Silver' level (NDUHD, 2010a) as the benchmark for visitability.

The study was guided by Dahler-Larsen's (2001) constructivist approach to program theory in the selection, collection and analysis of this data. This theory provided a framework to consider the separate elements of an initiative, and how they affected each other. In this study, policy was the voluntary provision of inclusive housing, interventions were the voluntary Livable Housing Design guidelines, and outcomes were the dwellings with Silver Level features (which can be affected by external influences). The interventions can be affected moderated by the agency of individuals which inhibit an intervention and, in turn, moderator interventions were intentional strategies to address these inhibitors. (See Figure 1 for relationship between the elements). 


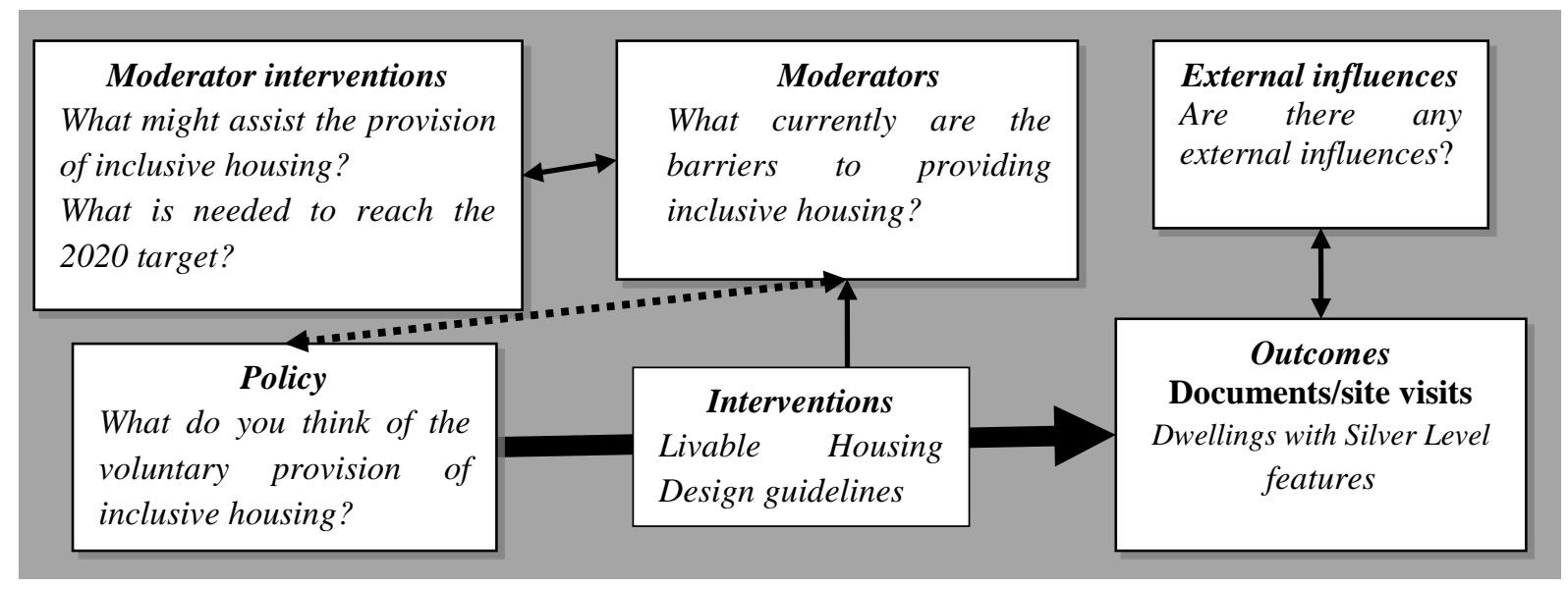

Figure 1. Program Theory elements with interview questions as they relate to the study (DahlerLarsen, 2001).

The study collected data from site-visits to the eleven dwellings, examination of building documents, and twenty-eight semi-structured interviews (See Figure 1 for the interview questions). The interviewees consisted of twelve developers (individuals who had a financial stake in the building outcome), eight designers (people who interpreted the developers' briefs into building contracts), three siterepresentatives (people who represented either the developer or designer on site) and five contracted builders involved with the eleven dwellings. This paper is limited to the thematic analysis of the data with regard to the moderators (or perceived barriers to building inclusive housing for the interviewees), and the moderator interventions (or what they considered might assist them to transform their practices to reach the 2020 target).

\section{Results}

\section{Moderators (perceived barriers)}

When the interviewees were asked to identify the barriers to providing inclusive housing, the most dominant theme was voluntariness. They did not provide inclusive housing because it was discretionary rather than a requirement. To change building practice voluntarily in a way that other providers may choose not to do was considered a risk not worth taking. Tom, a builder, explained: "If one builder is going to do it and he is pricing against another builder, who is not going to do it, that's a disadvantage".

The second most dominant theme was otherness. This was expressed in two ways: the first was that people needing inclusive housing generally were not part of 
the mainstream buying-market and their housing needs were already met in other ways (for example, group homes or retirement villages); the second was that the buying-market would consider inclusive housing as ugly, unnecessary and undesirable. James, a developer, expressed his concern that the need for access was over-estimated: "I mean to say, no-one wants to end up in a wheelchair but you got to look at, you know, the people that live in units, how many are in a wheelchair?" Another developer, Barry, anticipated a negative response to inclusive housing from his buyers: "Our sales-people don't see how they can even market the home[s]. They [would] actually stay silent on it".

A third theme was immediacy; the focus was on the anticipated buyer rather than on the long-term use of the dwelling. Marcus, a developer, said: "If you are pitching it at a young family, they are not really going to be interested in whether it is universal . . . it's not relevant to their daily activities". Kylie, a developer, also explained: "It's all about-it's a consumer-driven thing. Is there a market for it? Can it be sold?'

Finally, the analysis identified inertia as a theme; that is, there was reluctance to do things differently from what currently worked. Maintaining the status quo was reliable and minimised unexpected mistakes and time delays. Marje, a designer of private housing, explained: "I guess [they are] afraid of doing something that's going to change their routine, might expose them to risk, either financial risk or liability of some kind. . . . They could lose out in some way". There was also a culture of building by rote. James commented: "If I asked them, 'Why did you do it this way?' they [would] say, "Because I always have". Todd, a designer of both social and private housing, observed this was common practice: "We tend to see . . the same features from development to development".

\section{Moderator interventions (what might assist?)}

When the interviewees were asked what might assist them to provide inclusive housing, the dominant idea was direction from a higher authority to provide inclusive housing; everyone should be directed to comply to maintain a 'level playing field' in a competitive industry. Peter, a developer, explained: “We have to keep competing in the market-place. So, unless it's made compulsory, we would probably never go down that line". 
The next most dominant suggestion was demonstration that it made good business sense; that inclusive housing sells, is doable and is not costly. Some interviewees considered they might build inclusive housing if the larger companies took the lead and demonstrated that it was profitable. Barry, a developer from a leading company, supported this idea: "We are looking at how we can incorporate [access features] into our housing. . . . I also see [inclusive housing] as one opportunity for us to lead the market, to become a bit more innovative and to show the market what can be done". Two other suggestions supported this: an explanation of what inclusive housing actually meant for their practice; and education on costeffective ways to provide it.

Another suggestion was a clear, coherent message on the purpose of inclusive housing. Marje spoke of the good nature of the industry. She felt that a better understanding of the benefits of inclusive housing might convince individuals to change their practice: "I mean if people, builders, were made aware of the massive difference [access features] would make, they may be willing to accept the cost". This message was considered to be important also for buyers. Tom, a developer, suggested: "So, yes, I think there needs to be community awareness as to why it's good, why it's aspirational for homes to be designed like this".

Another dominant suggestion was increased buyer-demand for inclusive housing at the point of sale. Todd said: "It's a no-brainer from a commercial aspect (laugh), because, if the demand is there, we are going to provide it". This idea was tempered, however, by the understanding that most design decisions were made long before the individual buyer is identified. James explained: "The trouble with housing - the design is in place typically before the buyer comes along". Some interviewees suggested financial incentives as a strategy to change building practice although they cautioned that these were often compromised in practice by short-term political goals or administrative complexities.

\section{Moderator interventions (what might assist to reach the 2020 target?)}

Once the interviewees were asked to focus on what might assist them to reach the 2020 target, all but one interviewee identified that direction from a higher authority in the form of mandated regulation would be necessary. Interviewees identified two ways regulation should be introduced. The first group acknowledged that legislation was the usual strategy to address policy changes; the access standard for public 
buildings was given as an example. Therese, a developer, said: "I don't know why there would be a resistance [to] having it as regulation, because just about everything else in the building process is regulated". The second group argued for a developmental process to legislation. Kylie explained: "You just couldn't come in and say, "This is what we are doing". You would have to work with everyone. . . And it's not an easy process, and it probably will take six years, so, if not more". The exception was Jackson, a designer, who acknowledged the complexity of "bringing the industry along": "I think you would probably get a better response with incentives than with legislation, to be honest-quickly".

\section{Discussion}

Within the limited scope and size of the study, the findings suggest that, to reach the 2020 target, a legislative approach would be necessary. The findings also suggest the Livable Housing Design initiative has an important developmental role to play in the housing industry's understanding of the need, how it can be provided and eventual acceptance of legislation. This section now looks at each of the three supporting assumptions (trusteeship, self-determination, and sense-of-duty) in relation to these findings.

\section{Trusteeship}

The first supporting assumption was that individual players in the housing industry would consider the needs of occupants and visitors of the dwelling throughout its lifetime. The study found instead that the interviewees were more likely to focus on meeting their immediate contractual obligations. People who needed inclusive housing were seen as separate from the mainstream housing-market, therefore, not of their concern. The interviewees, however, considered that individuals within the housing industry might respond positively to a clear, coherent message about the purpose of inclusive housing. The Livable Housing Design initiative aims to do this by describing inclusive housing as aspirational for everyone. Its strategic plan explains: "A universally designed home seeks to enhance the quality of life for all occupants at all stages of their life by including safer and more user friendly design features" (NDUHD, 2010b). 


\section{Self-determination}

The second supporting assumption was that housing providers would proceed with objective reasoning. The study found instead that interviewees were more likely to take "the path of least resistance" to deliver their product. The theme of inertia in the form of reluctance to change current practices and building-by-rote suggested a lack of reasoned thought about what could, or should, be provided within their practice. Demonstration that building inclusive housing was doable, reasonable, and profitable might assist them to consider a change in practice. The Livable Housing Design initiative attempts to do this by publicising in their news bulletin new developments that meet the guidelines (Livable Housing Australia, 2013).

\section{Sense-of-duty}

The third supporting assumption is that housing providers will do the right thing voluntarily before being directed to do so. The study found instead that the interviewees were unlikely to do more than was currently required of them. Interviewees saw little reason to provide inclusive housing unless they were directed or there was a consistent demand from the buying-market. If the 2020 target was to be reached, the interviewees favoured legislation as a strategy over relying on market-forces. The buying-market was considered to be too unreliable and variable to influence the provision of inclusive housing reliably to reach the target.

Further research on both buyer-demand and incentives would contribute to this study. The anticipated older population (Australian Bureau of Statistics, 2010b) whose preference is to remain active in family and community life (Ozanne, 2009) appear to be the most likely cohort to consider inclusive housing as an option. The potential of incentives in this area has not been tested with a reliable long-term example, with the exception of Japan (Kose, 2003); however, the use of incentives is increasingly becoming a preferred strategy for social change (Sandel, 2012).

Acknowledging its limited size and scope, the study found the Livable Housing Design initiative's assumption that the Australian housing industry will respond voluntarily to providing inclusive housing is unfounded. The interdependent, highlycompetitive and risk-averse nature of the industry is at odds with a voluntary approach and a mandatory approach is indicated if the 2020 target is to be reached. The Livable Housing Design initiative, however, has an important developmental role in preparing the Australian housing industry for this legislation. 


\section{Conclusion}

At the close of 2013, The Livable Housing Design initiative identified less than a thousand new dwellings nationally with Silver level features or above (Livable Housing Australia, 2013) towards the anticipated target of 25\% (approximately 35,000 new dwellings) of the annual new housing stock (National Housing Supply Council, 2011). The outlook for the Livable Housing Design initiative is grim. So who cares about the Dialogue's agreement, the lack of inclusive housing or the consequences for people like Joan? And who will act? With the housing industry reluctant to act and the buying-market not as yet interested; the task falls on the individual buyer needs these access features or the government.

Previously noted, Australian governments are currently reluctant to intervene where a voluntary agreement has been struck. Unless housing providers are required to provide access features by law, the individual buyers have a formidable task. They must know what features they need, advocate for them, pay extra for them, and monitor that they have been provided properly (Bringolf, 2011a).

For lasting systemic change in the provision of inclusive housing, it will again be up to the people like Joan and their advocates to take action. They have three tasks. They will need to remind the Australian Government of its policy commitments to create inclusive residential communities. They will need to convince the Australian Building Codes Board this market-failure with its flow-on effects warrants regulation. Finally, they will need to persuade the Australian housing industry that mandated requirements will benefit everyone.

\section{References}

Australian Buillding Codes Board [ABCB]. (2011). Home page. Retrieved from http://www.abcb.gov.au/en

Australian Institute of Health and Welfare [AlHW]. (2012). Housing assistance in Australia 2012. Canberra.

Australian Bureau of Statistics [ABS]. (2010a). Disability, ageing and carers, Australia: Summary of findings. Retrieved from http://www.ausstats.abs.gov.au/ausstats/subscriber.nsf/0/9C2B94626F0FAC6 2CA2577FA0011C431/\$File/44300 2009.pdf

Australian Bureau of Statistics. (2010b). Household and family projections, Australia, 2006 to 2031. Retrieved from http://www.abs.gov.au/AUSSTATS/abs@.nsf/DetailsPage/3236.02006\%20to \%202031? OpenDocument 
Australian Government. (2010). A stronger, fairer Australia. Retrieved from http://www.socialinclusion.gov.au/Resources/Documents/ReportAStrongerFair erAustralia.pdf

Australian Government. (2011a). 2010-2020 National disability strategy: An initiative of the Council of Australian Governments. Canberra: Commonwealth of Australia.

Australian Government. (2011b). Our Cities, Our Future: a national urban policy framework for a productive, sustainable and liveable future. Canberra: Department of Infrastructure and Transport Retrieved from http://www.infrastructure.gov.au/infrastructure/mcu/files/Our Cities National Urban Policy Paper 2011.pdf

Australian Network for Universal Housing Design. (2011). Strategic plan 2011-2013. . Retrieved from http://www.anuhd.org/content/strategic-plan

Beck, U. (1996). The reinvention of politics: Rethinking modernity in the global social order. Cambridge, Mass: Polity Press.

Beer, A., \& Faulkner, D. (2009). 21st century housing careers and Australia's housing future. AHURI Final Report No. 128. Retrieved from http://www.ahuri.edu.au/nrv/nrv2/NRV2 Assoc Docs.html

Bringolf, J. (2009). Calling a spade a shovel: Universal, accessible, adaptable, disabled - aren't they all the same? Paper presented at the 4th Australasian Housing Researchers' Conference Sydney. Retrieved from http://www.fbe.unsw.edu.au/cf/apnhr/

Bringolf, J. (2011a). Barriers to universal design in housing. Urban Research Centre, College of Health and Science. Retrieved from http://handle.uws.edu.au:8081/1959.7/506910

Bringolf, J. (2011b). The Landcom Universal Housing Design Guidelines:best practice or wishful thinking? Access by Design, Winter 2011(129), 16-17.

Crabtree, L., \& Hes, D. (2009). Sustainability uptake in housing in metropolitan Australia: An institutional problem, not a technological one. Housing Studies, 24(2), 203-224.

Dahler-Larsen, P. (2001). From programme theory to constructivism: On tragic, magic and competing programmes. Evaluation, 7(3), 331.

Dalton, T., Chhetri, P., Corcoran, J., Groenhart, L., \& Horne, R. (2011). Understanding the patterns, characteristics and trends in the housing sector labour force in Australia. AHURI Positioning Paper, no.142. Melbourne.

Dalton, T., Wakefield, R., \& Horne, R. (2011). Australian suburban house building:industry organisation, practices and constraints. AHURI Positioning Paper, no. 143. Melbourne.

Department of Public Works. (2008). Smart and sustainable homes design objectives. Brisbane: Queensland Government.

Disability Investment Group. (2009). The way forward. Canberra: Australian Government.

Housing Industry Association. (2010). Submission by the Housing Industry Association to the Department of Planning and Community Development on the regulatory impact statement into visitable and adaptable housing. Retrieved

from http://hia.com.au/media/ /media/Files/MediaMicrosite/Submissions/Visitable\% 20and\%20Adaptable\%20Housing\%20-\%20Victoria.ashx 
Housing Industry Association. (2011). Accessibility in residential buildings. Retrieved from

http://hia.com.au/hia/content/Policy/region/National/classification/Building\%20 Policy/article/IS/HP/Accessibility\%20in\%20Residentail\%20Buildings.aspx

Imrie, R. (2006). Accessible housing: Quality, disability and design. London: Routledge.

Judd, B., Olsberg, D., Quinn, J., \& Demirbilek, O. (2010). Dwelling, land and neighbourhood use by older home owners. AHURI final report No. 144. Melbourne.

Kaminski, S. E., Mazumdar, S., DiMento, J. F., \& Geis, G. (2006). The Viability of Voluntary Visitability A Case Study of Irvine's Approach. Journal of Disability Policy Studies, 17(1), 49-56.

Karol, E. (2008). Inclusive design and the new home market: The West Australian situation. Architectural Science Review, 51(1), 80-83.

Kose, S. (2003). The Japanese Experience. In P. Clarkson, R. Coleman, S. Keates \& C. Lebbon (Eds.), Inclusive Design: Design for the whole population (pp. 308-316). Springer-Verlag.

Kose, S. (2010). How can the exploding senior population be accommodated?: Japanese struggle towards inclusive design. Journal of Engineering Design, 21(2), 165-171.

Livable Housing Australia. (2013). Livable housing update: July 2013. Retrieved from http://d19cgyi5s8w5eh.cloudfront.net/eml/66V80V5Y-VUW6-425U-946W6127U1V734V2?e=anuhd.network\%40gmail.com\&a=X6U51317-009U-41978V68-8UU8252U4447\& $\mathrm{f}=\& \mathrm{t}=1$

Maisel, J. (2006). Toward inclusive housing and neighborhood design: A look at visitability. Community Development, 37(3), 26-34.

Major Cities Unit. (2012). State of Australian Cities 2012. Canberra: Australian Government.

Master Builders Association (ACT). (2001). Housing for life. Retrieved from http://www.mba.org.au/public/page.php?id=79

Milner, J., \& Madigan, R. (2004). Regulation and innovation: Rethinking 'inclusive' housing design. Housing Studies, 19(5), 727-744.

National Housing Supply Council. (2011). Key findings of the 2011 state of supply report. Canberra: Australian Government.

National People with Disabilities and Carer Council. (2009). Shut Out: The Experience of People with Disabilities and their Families in Australia. Canberra: Australian Government.

National Dialogue on Universal Housing Design [NDUHD]. (2010a). Livable housing design guidelines. Retrieved from http://www.dss.gov.au/sites/default/files/documents/09 2012/lhd guidelines 2 012 secondedition $1 . p d f$

National Dialogue on Universal Housing Design [NDUHD]. (2010b). Strategic plan. Retrieved from http://www.dss.gov.au/sites/default/files/documents/05 2012/national dialogu e strategic plan.pdf

Nishita, C., Liebig, P., Pynoos, J., Perelman, L., \& Spegal, K. (2007). Promoting basic accessibility in the home: Analyzing patterns in the diffusion of visitability legislation. Journal of Disability Policy Studies, 18(1), 2-13.

Ozanne, E. (2009). Negotiating identity in late life: Diversity among Australian baby boomers. Australian Social Work, 62(2), 132-154. 
People with Disability Australia. (2010). Accommodating human rights: A human rights perspective on housing, and housing and support for persons with disability.

Productivity Commission. (2004). Reform of building regulation. Retrieved from http://129.3.20.41/eps/othr/papers/0506/0506007.pdf

Productivity Commission. (2011). Caring for older Australians: Productivity Commission inquiry report. Canberra: Australian Government.

Sabia, D. (2010). Defending immanent critique. Political Theory, 38(5), 684-711.

Sandel, M. (2012). What money can't buy. New York: Farrer, Straus and Giroux.

Saugeres, L. (2010). (Un)accommodating disabilities: Housing, marginalization and dependency in Australia. Journal of Housing and the Built Environment, 26(1), 1-15.

Scotts, M., Saville-Smith, K., \& James, B. (2007). International trends in accessible housing for people with disabilities. Retrieved from http://scholar.google.com.au/scholar?q=International+Trends+in+Accessible+ Housing+for+People+with+Disabilities.\&hl=en\&btnG=Search\&as sdt=2001\&a s sdtp=on

Smith, S., Rayer, S., \& Smith, E. (2008). Aging and disability: Implications for the housing industry and housing policy in the United States. Journal of the American Planning Association, 74(3), 289-306.

Smith, S., Rayer, S., Smith, E., Wang, Z., \& Zeng, Y. (2012). Population Aging, Disability and Housing Accessibility: Implications for Sub-national Areas in the United States. Housing Studies, 27(2), 252-266.

Spanbroek, N., \& Karol, E. (2006, October 23-25). Ageing at home-are we prepared? Paper presented at the The 2nd International Conference for Universal Design, Kyoto, Japan.

Standards Australia. (1995). Adaptable housing AS4299. Sydney: Standards Australia.

Truesdale, S., Steinfeld, E., \& Smith, E. (2002). Visit-ability: An approach to universal design in housing: Rehabilitation Engineering Research Center on Universal Design, School of Architecture and Planning, University at Buffalo.

United Nations. (2007). Convention on the rights of persons with disabilities and optional protocol. Retrieved from http://www.un.org/disabilities/default.asp?navid=14\&pid=150

US Census Bureau. (2008). Americans with disabilities: 2005. Washington DC: Retrieved from http://www.census.gov/prod/2008pubs/p70-117.pdf

Victorian Building Commission. (2009). Build for life. Retrieved from http://www.buildingcommission.com.au/www/html/2218-build-for-life.asp

\section{Biographical notes}

Margaret Ward completed her $\mathrm{PhD}$ at the School of Design at Queensland University of Technology. Originally trained in architecture, she has spent much of her career working towards the adoption of housing design which includes everyone regardless of age and ability. Her thesis explored the notions of voluntariness and responsibility in providing inclusive housing within a framework of distributive justice. 
Jill Franz is Professor of Interior Design and has thirty years' experience in design and design research, focusing on socially-responsible design and the experiential relationship of people and environment. She has had extensive involvement in various design practice and research projects enabling independent communityliving for people with disability. Her interests also include participatory and consensus approaches to design and design education.

Barbara Adkins is a sociologist and Associate Professor in the School of Design. She has research interests in the area of design for health and social inclusion; the role of technologies and new media in social participation; qualitative inquiry; and the pedagogy of research supervision. She has been a chief investigator on nineteen research projects including $\mathrm{ARC}, \mathrm{AHURI}, \mathrm{CRCs}$, and other research consultancies.

\section{Appendix: Livable Housing Design guidelines: Silver level}

\section{Performance statements (NDUHD 2010a) \\ Dwelling access}

There is a safe and continuous pathway from the street entrance and/or parking area to a dwelling entrance that is level.

\section{Dwelling entrance}

There is at least one level entrance into the dwelling to enable home occupants to easily enter and exit the dwelling.

\section{Car parking (where part of the dwelling access)}

Where the parking space is part of the dwelling access it should allow a person to open their car doors fully and easily move around the vehicle.

\section{Internal doors and corridors}

Internal doors and corridors facilitate comfortable and unimpeded movement between spaces.

\section{Toilet}

The ground (or entry) level has a toilet to support easy access for home occupants and visitors.

\section{Shower}

The bathroom and shower is designed for easy and independent access for all home occupants. 


\section{Reinforcement of bathroom and toilet walls}

The bathroom and toilet walls are built to enable grab-rails to be safely and economically installed.

\section{Less than $5 \mathrm{~mm}$ transition between internal spaces}

Internal doors and corridors facilitate comfortable and unimpeded movement between spaces. 